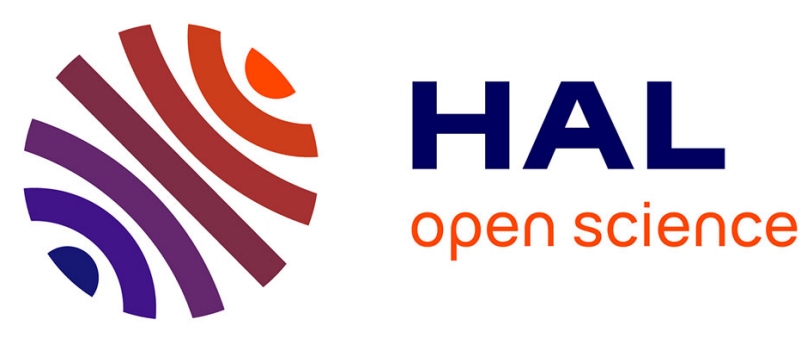

\title{
Variation of total mercury concentration in different tissues of three neotropical caimans: implications for minimally invasive biomonitoring
}

Jérémy Lemaire, Francois Brischoux, Olivier Marquis, Mangione Rosana, Paco

Bustamante

\section{To cite this version:}

Jérémy Lemaire, Francois Brischoux, Olivier Marquis, Mangione Rosana, Paco Bustamante. Variation of total mercury concentration in different tissues of three neotropical caimans: implications for minimally invasive biomonitoring. Archives of Environmental Contamination and Toxicology, 2021, 81, pp.15-24. 10.1007/s00244-021-00846-y . hal-03193861

\section{HAL Id: hal-03193861 \\ https://hal.science/hal-03193861}

Submitted on 11 Jan 2022

HAL is a multi-disciplinary open access archive for the deposit and dissemination of scientific research documents, whether they are published or not. The documents may come from teaching and research institutions in France or abroad, or from public or private research centers.
L'archive ouverte pluridisciplinaire HAL, est destinée au dépôt et à la diffusion de documents scientifiques de niveau recherche, publiés ou non, émanant des établissements d'enseignement et de recherche français ou étrangers, des laboratoires publics ou privés. 
Variation of total mercury concentration in different tissues of three neotropical caimans: implications for minimally invasive biomonitoring

Jérémy Lemaire ${ }^{\mathrm{a}, \mathrm{b} *}$, François Brischoux ${ }^{\mathrm{a}}$, Olivier Marquis ${ }^{\mathrm{c}}$, Rosanna Mangione ${ }^{\mathrm{d}}$, Paco Bustamante $\mathrm{e}^{\mathrm{b}, \mathrm{e}}$

a Centre d'Études Biologiques de Chizé (CEBC), UMR 7372 CNRS-La Rochelle Université, 79360 Villiers en Bois, France

${ }^{\mathrm{b}}$ Littoral Environnement et Sociétés (LIENSs), UMR 7266 CNRS-La Rochelle Université, 2 rue Olympe de Gouges, 17000 La Rochelle, France

${ }^{\text {c }}$ Sorbonne Université, Muséum national d'Histoire naturelle, Parc Zoologique de Paris, 53 avenue de Saint Maurice, 75012 Paris, France

${ }^{\mathrm{d}}$ Haus des Meeres Aqua Terra Zoo GmbH, Fritz-Grünbaum Platz 1, 1060 Vienna, Austria

${ }^{\mathrm{e}}$ Institut Universitaire de France (IUF), 1 rue Descartes 75005 Paris, France

*Address correspondence to jeremy.lemaire@univ-lr.fr

\section{DECLARATIONS}

Funding: Not applicable.

Competing interest: The authors have no competing interests to declare.

Availability of data and material: Data are available from the corresponding author (jeremy.lemaire@univ-lr.fr).

Code availability: Not applicable. 
Authors' contributions: J. Lemaire, F. Brischoux, O. Marquis, R. Mangione, P. Bustamante conceived and designed experiments. J. Lemaire, F. Brischoux performed statistical analysis. J. Lemaire performed chemical analysis. J. Lemaire, F. Brischoux, O. Marquis, R. Mangione, P. Bustamante wrote the manuscript.

Ethics approval: Permission to capture individuals, draw blood and sample claws and scutes was granted by the French authorities (Direction Régionale des Territoires et de la Mer) after evaluation by the CSRPN, the regional scientific committee (Permit: R03-2016-06-21-010; R03-2019-01-09-001; R03-2019-10-24-007, www.guyane.developpement-durable.gouv.fr). 


\section{Abstract}

Mercury $(\mathrm{Hg})$ is a global environmental contaminant that affects ecosystems. It is known to biomagnify through food webs, and to bioaccumulate especially in the tissues of top predators. Large scale comparisons between taxa and geographic areas are needed to reveal critical trends related to $\mathrm{Hg}$ contamination and its deleterious effects on wildlife. Yet, the large variety of tissues (keratinized tissues, internal organs, blood) as well as the variability in the units used to express $\mathrm{Hg}$ concentrations (either in wet- or dry-tissue weight) limits straightforward comparisons between studies. In the present study, we assessed the moisture content that could influence the total $\mathrm{Hg}(\mathrm{THg})$ concentrations measured in several tissues (claws, scutes, total blood and red blood cells) of three caiman species. First, we aimed to evaluate the moisture content from the different tissues, and second to provide information on $\mathrm{THg}$ concentrations in various matrices. Our results show a difference of $\mathrm{THg}$ concentrations between the tissues and intra- and interspecific variations of moisture content, with the highest $\mathrm{THg}$ values found in keratinized tissues (scute keratinized layers and claws). For the three species, we found positive relationships between body size and $\mathrm{THg}$ concentration in keratinized tissues. In the blood, the relationship between body size and $\mathrm{THg}$ concentration was species-dependent. Our results emphasize the need for a standardized evaluation of THg concentration and trace elements quantification based on dry weight analytical procedures. In addition, the use of both blood and keratinized tissues offers the possibility to quantify different time scales of THg exposure by non-lethal sampling.

Keywords: Trace metals, Ecotoxicology, Keratinized tissues, Crocodilians, Bioaccumulation 


\section{INTRODUCTION}

Mercury (Hg) is one of the major contaminants of concern in ecosystems (Ericksen et al. 2003; Fitzgerald et al. 2007; Selin 2009). In addition to naturally present geological $\mathrm{Hg}$, human activities such as deforestation, fossil fuel combustion and gold mining activities have been shown to increase the level of $\mathrm{Hg}$ in the environment, particularly in aquatic ecosystems (Ericksen et al. 2003; Scheuhammer and Sandheinrich 2007; Hsu-Kim et al. 2018). In anoxic conditions, aquatic microorganisms can transform inorganic $\mathrm{Hg}$ into methylmercury ( $\mathrm{MeHg})$, the most bioavailable and toxic form of Hg (Jensen and Jernelöv 1969; Benoit et al. 2003). Importantly, MeHg biomagnifies through food webs, and bioaccumulates in the tissues of top predators, which makes them particularly vulnerable to this contaminant (Eagles-Smith et al. 2018).

Crocodilians belong to the World's largest predators and as such, they have important functions in ecosystems and can constitute indicators of ecosystem health (Somaweera et al. 2020). As apex predators, crocodilians bioaccumulate environmental contaminants that biomagnify across food webs, and thus can be particularly vulnerable to their toxicity (Cook et al. 1991; Camus et al. 1998; Rainwater et al. 2007). Therefore, they are relevant bioindicators regarding environmental contamination (Guillette et al. 1994; Manolis et al. 2002; Campbell et al. 2003; Chumchal et al. 2011; Schneider et al. 2015). In addition, such an evaluation is also useful to determine the relatively poorly known detrimental effects of contaminants on this taxon, such as physiological and reproductive impairment and DNA damages (Guillette et al. 2000; Siroski et al. 2016; Burella et al., 2018; Lemaire et al. 2021a).

Crocodilians bioaccumulate $\mathrm{Hg}$ at various concentrations, depending on the species and on the location (Elsey et al. 1999; Rumbold et al. 2002; Campbell et al. 2010; Vieira et al. 2011; Nilsen 
et al. 2017a; Lemaire et al. 2021a). However, interspecific variability across the whole group remains still poorly understood to date as most of the available studies on $\mathrm{Hg}$ concentrations have disproportionately focused on two species, the American Alligator, Alligator mississippiensis and the Morelet's Crocodile, Crocodylus moreletii (Yanochko et al. 1997; Jagoe et al. 1998; Elsey et al. 1999; Burger et al. 2000; Rainwater et al. 2007; Horai et al. 2014; Trillanes et al. 2014; Nilsen et al. 2017a; Buenfil-Rojas et al. 2018; Nilsen et al. 2019; BuenfilRojas et al. 2020). Some recent studies, however, have focused on several other species (Almli et al. 2005; Vieira et al. 2011; Lázaro et al. 2015; Schneider et al. 2015; Marrugo-Negrete et al. 2019; Lemaire et al. 2021a,b). Furthermore, $\mathrm{Hg}$ concentrations in crocodilians have been determined in a variety of tissues (blood, muscles, internal organs or keratinized tissues), depending on the study, which limits robust comparisons between them. It is worth noting that the associated methodologies (e.g., sample preparation and tissues studied) are variable, which also limits straightforward comparisons between studies (Schneider et al. 2015). Further, THg concentrations in these papers are either presented as the concentration relative to the wet-, or dry-weight of sampled tissues. Clearly, such discrepancy prevents direct comparison between studies, especially as the amount of tissue moisture content, and its variation within and across tissues, on $\mathrm{Hg}$ concentration has not yet been thoroughly investigated. In addition, one of the most studied tissues in crocodilians is the muscle, most likely because it is used for human consumption (Delany et al. 1988; Elsey et al. 1999; Eggins et al. 2015; Rivera et al. 2016). Although assessing $\mathrm{Hg}$ contamination in such tissue can be useful, many species are now classified by the IUCN as in danger of extinction, which supports both the reduction of crocodile hunting per se, and the development of specific, non-lethal sampling methods to assess their $\mathrm{Hg}$ contamination levels and its effects (as methods have shown for other reptile species, Day et al. 2005; Lemaire et al. 2018; Beau et al. 2019). 
In this context, the goals of the present study were two-fold: first, we assessed the moisture content of different tissues (claws, scutes and total blood) and investigated the influence of sample preparation on total $\mathrm{Hg}(\mathrm{THg})$ quantification, in order to provide recommendations to harmonize $\mathrm{Hg}$ assessment across multiple matrices. Second, we compared $\mathrm{THg}$ concentrations between several tissues (full scutes, scute keratin layers, claws, total blood and red blood cells) to evaluate the use of non-lethal sampling methods to facilitate future comparisons of contamination in crocodilians.

\section{MATERIALS AND METHODS}

\section{Sample collection}

Our study was conducted in French Guiana between April 2016 and February 2020 (Fig. 1). We sampled 51 individuals of smooth-fronted caiman, Paleosuchus trigonatus (Schneider, 1801) from 6 different sites, 48 individuals of spectacled caiman, Caiman crocodilus (Linnaeus, 1758) from 2 different sites and 13 individuals of dwarf caiman, Paleosuchus palpebrosus (Cuvier, 1807) from 4 different sites. P. trigonatus were captured in small forest streams, $C$. crocodilus and $P$. palpebrosus were captured in marsh or stream habitats.

The snout-vent length (SVL) and total length (TL) of each individual were measured. We took claw (randomly at the posterior legs) and scute samples (in all samplings $<1 \mathrm{~cm}$, and never exceeding half of the scute) of all caimans using pliers for clipping the sample. Clipping tail scutes is a common marking method in crocodilians. The scutes which were clipped in order to mark the captured individuals were therefore not the same for all animals as they followed the consecutive identification code. Claw and scute samples were placed in dry plastic containers. Blood was collected on a subsample of individuals depending on the field possibilities $(\mathrm{N}=24$ for $P$. trigonatus, $\mathrm{N}=40$ for $C$. crocodilus and $\mathrm{N}=7$ for $P$. palpebrosus $)$. Blood samples $(0.2$ 
$-3 \mathrm{ml}$ ) were drawn from the lateral tail vein using 27 gauges $-25 \mathrm{~mm}$ or 21 gauges $-50 \mathrm{~mm}$ (depending on the size of the individual animal) heparinized needles (heparin sodium). Each blood sample was separated into two tubes and kept at cold temperatures $\left(4^{\circ} \mathrm{C}\right)$ until being processed at the laboratory (always $<3 \mathrm{~h}$ after collection). The first tube, containing total blood, was frozen at $-28^{\circ} \mathrm{C}$ in the lab. The second one was centrifuged at $6500 \mathrm{rpm}$ for 5 minutes to separate red blood cells (RBCs) and plasma, after which both fractions were then frozen at $28^{\circ} \mathrm{C}$ in the lab until analysis.

After sampling, each individual was released at its capture location.

C. crocodilus, P. trigonatus and P. palpebrosus are protected by the French law (Ministerial decree NOR: TREL1933710A of 08/10/2018) and a permission to capture individuals, draw blood and sample claws and scutes was granted by the French authorities (Direction Régionale des Territoires et de la Mer) after evaluation by the CSRPN, the regional scientific committee (Permit: R03-2016-06-21-010; R03-2019-01-09-001; R03-2019-10-24-007, www.guyane.developpement-durable.gouv.fr).

\section{Sample preparation}

Claws and scutes were cleaned for 5 minutes in an ultrasonic bath of ultrapure water to remove all external dirt and rinsed 3 times, as described in Lemaire et al. (2021a). In order to assess the wet weight of claws and scutes, we weighed cleaned samples after elimination of water surplus with absorbent paper. Because cleaning procedures were relatively short and because caimans are semi-aquatic species which spend most of their lifetime immerged in water, our cleaning procedures were not likely to influence wet weight assessment. In order to assess dry weight, each sample was dried in an oven for $48 \mathrm{~h}$ at $45^{\circ} \mathrm{C}$, which was found to be sufficient to reach stable weight (no difference was found when dried at $45^{\circ} \mathrm{C}$ for $48 \mathrm{~h}, 72 \mathrm{~h}$ and $96 \mathrm{~h}$, data not shown). Moisture content was calculated as wet weight minus dry weight and expressed as a 
proportion of wet weight for further analyses. A subsample of dried scutes $(\mathrm{N}=26$ for $C$. crocodilus, $\mathrm{N}=4$ for $P$. palpebrosus and $\mathrm{N}=4$ for $P$. trigonatus) was used to perform comparison of $\mathrm{Hg}$ concentrations between these matrices. We separated the external layer, which is composed of keratin (corneoscute), from the underlying connective tissue which is the link between bone/cartilage (osteoscute) and the keratin layer. For the remaining scute samples, only the keratin layer was analysed. In order to assess the moisture of total blood and RBC samples, we weighted the samples before and after the freeze-drying process (48h). Freezedried samples were then ground into a homogeneous powder. The moisture content of total blood and RBC samples was calculated as wet weight minus dry weight and then expressed as a proportion of wet weight.

\section{Instrumental method and quality control}

For all samples, total $\mathrm{Hg}$ ( $\mathrm{THg}$ ) was determined using an atomic absorption spectrometer AMA254 (Advanced Mercury Analyser-254; Altec $($ ). At least two replicates of $0.3-1.0 \mathrm{mg}$ dry weight $(\mathrm{dw})$ were analysed for each sample. The reproducibility for duplicate samples was approved when relative standard deviation (RSD) was below 10\%. The analyses of certified reference material (CRM) TORT-2 (Lobster hepatopancreas from the National Research Council of Canada; certified Hg concentration: $0.27 \pm 0.06 \mu \mathrm{g} \cdot \mathrm{g}^{-1} \mathrm{dw}$ ) and TORT-3 (Lobster hepatopancreas from the National Research Council of Canada; certified Hg concentration: $0.292 \pm 0.022 \mu \mathrm{g} \cdot \mathrm{g}^{-1} \mathrm{dw}$ ) was performed at the beginning and at the end of the analytical cycle and every 10 samples, for the validation of the method. The TORT-2 measured value was 0.243 $\pm 0.015 \mu \mathrm{g} \cdot \mathrm{g}^{-1} \mathrm{dw}(\mathrm{n}=20)$, giving a recovery of $90.2 \pm 5.7 \%$ and the TORT-3 measured value was $0.289 \pm 0.007 \mu \mathrm{g} \cdot \mathrm{g}^{-1} \mathrm{dw}(\mathrm{n}=30)$ giving a recovery of $99.0 \pm 2.3 \%$. Blanks were included at the beginning of analytical runs and the limit of quantification of the AMA was $0.05 \mathrm{ng}$. THg concentrations are expressed in $\mu \mathrm{g} \cdot \mathrm{g}^{-1} \mathrm{dw}$. 


\section{Statistical analysis}

All statistical analyses were performed using the software R, v.3.6.1 ( $R$ development Core Team). All data were checked for normality and homogeneity of variances. Depending on the results, parametric or non-parametric tests were used. The differences of moisture content in each tissue between species, as well as the differences of moisture content between different tissues for each species, and the differences of moisture content for each species and each tissue between capture sites were all investigated by Kruskal-Wallis test.

Paired t-tests were used to compare $\mathrm{THg}$ concentrations between full scutes (a combination of keratin, bone and connective tissue) and scute keratin layers for each species. To access the relationship between $\mathrm{THg}$ concentrations in full scutes and scute keratin layers, we built a predictive equation for $C$. crocodilus. The predictive equation was built for a significant relationship between both tissues, using slope and intercept derived from the parametric linear regression line. To validate the models, bootstrapping with 1000 iterations were applied (Harrell 2015). We did not build predictive equations for P. palpebrosus and P. trigonatus due to the restricted number of samples.

The difference of THg concentrations between tissues was assessed by Friedman ANOVA and Pairwise Bergmann-Hommel comparisons for each species. We performed Spearman rank tests to assess the relationships between body size (SVL and LT) and THg concentrations in the tissues, independently for each species.

The significance level for statistical analyses was always set at $\mathrm{p}<0.05$. 


\section{RESULTS}

\section{Moisture content}

The results of the moisture content of blood, claws and scutes for each species are summarized in Table 1. We found significant differences in moisture content between the species for claws (Kruskal-Wallis: $\mathrm{X}^{2}=22.79, \mathrm{p}<0.001, \mathrm{n}=57$ ) and full scutes (Kruskal-Wallis: $\mathrm{X}^{2}=10.66, \mathrm{p}$ $<0.005, \mathrm{n}=58$ ), but not for total blood (Kruskal-Wallis: $\mathrm{X}^{2}=1.11, \mathrm{p}=0.57, \mathrm{n}=31$ ) (Table 1, Fig. 2).

We did not find any geographic variation in moisture content of the different tissues for the three species (all $\mathrm{p}>0.18$ ).

\section{THg concentrations in scutes}

Our results show significantly higher concentrations of $\mathrm{THg}$ in scute keratin layers than full scutes in two species (Paired t-test: C. crocodilus, $\mathrm{t}=-5.44, \mathrm{p}<0.001 ;$ P. trigonatus, $\mathrm{t}=-4.71$, $\mathrm{p}=0.02 ;$ P. palpebrosus $, \mathrm{t}=-2.18, \mathrm{p}=0.12$, Fig. 3 ).

Our results do not show significant differences of $\mathrm{THg}$ concentration between the two capture sites (site 2, $\mathrm{n}=11$; site $8, \mathrm{n}=15$, see Fig.1) for full scutes and scute keratin layers of $C$. crocodilus ( $\mathrm{t}$-test: $\mathrm{t}=0.24, \mathrm{p}=0.815$ and $\mathrm{t}=0.15, \mathrm{p}=0.882$, respectively). Because no significant differences were found between sites, all C. crocodilus were pooled. A positive significant relationship was found between $\mathrm{THg}$ concentrations in full scutes and the scute keratin layers for $C$. crocodilus (linear regression: $\mathrm{F}_{1-24}=93.67, \mathrm{R}^{2}=0.78, \mathrm{p}<0.001$, Fig. 4 ). The significant level of the predictors and the upper and lower bounds of the $95 \%$ confidence interval $(\mathrm{CI})$ are given by the equation $\left(\mathrm{R}^{2}=0.788\right.$; $\mathrm{p}<0.001 ; 95 \% \mathrm{CI}$ : $\left.0.518-0.938\right)$ : 
$\mathrm{THg}$ scute keratin layers $=0.525 \mathrm{x}$ THg full scute +0.321

where THg in keratin layers and full scutes are expressed in $\mu \mathrm{g} \cdot \mathrm{g}^{-1} \mathrm{dw}$.

\section{Relation between tissues}

Our results show a significant difference of $\mathrm{THg}$ concentrations between tissues within each of the three species (Friedman ANOVA: P. trigonatus, $\mathrm{X}^{2}=20, \mathrm{p}<0.001 ;$ C. crocodilus, $\mathrm{X}^{2}=$ 91.33, $\mathrm{p}<0.001 ;$ P. palpebrosus, $\mathrm{X}^{2}=19.04, \mathrm{p}<0.001$, respectively, Table 2$)$. The $\mathrm{THg}$ concentrations were always higher in claws and scutes than in total blood and RBCs (Fig. 5). The relationships between body size and THg concentrations in the different tissues, and the relationships between tissues were assessed by Spearman rank test for the three species and summarized in Table 3.

\section{DISCUSSION}

\section{Moisture content}

Our results show a strong inter- and intraspecific variability of moisture content between tissues (Table 1, Fig. 2). Indeed, claws are mainly composed of alpha-keratin and present the lowest moisture content, while scutes are mainly composed of beta-keratin in association with osteoscutes and connective tissues which increases water content (Richardson et al. 2002). In contrast to the study of Yanochko et al. (1997), in which study sites were separated by a very large distance, we did not find any geographic differences regarding moisture content in the examined tissues, which may be linked to the more restricted area of our study. Our results suggest that the relatively large variation of moisture content in fresh samples can induce variations in terms of trace element quantification, including THg concentration. This seems 
particularly the case for keratinized tissues, while moisture content in blood samples was less variable. Overall, our assessment of the moisture content in various tissues clearly suggests that the use of dry samples for quantification should be favoured in order to facilitate future largescale comparisons of contamination in crocodilians. Alternatively, the moisture content of the tissues should be specified when trace element concentrations are expressed in wet weight in order to allow straightforward conversion between units.

\section{THg concentration: scute keratin layers vs. full scutes}

Clipping tail scutes is a common sampling method in crocodilians which further allows identification of the animal and can be used for DNA, stable isotopes and contaminant analyses (Jagoe et al. 1998; De Thoisy et al. 2006; Rainwater et al. 2007; Machkour-M'Rabet et al. 2009; Trillanes et al. 2014; Pacheco-Sierra et al. 2016; Santos et al. 2018; Lemaire et al. 2021a). The skin of crocodilians is composed of bony scutes covered by connective tissue and keratin layers (Richardson et al. 2002; Alibardi 2003). Although several studies reported concentrations of Hg in crocodilian scutes (Jagoe et al. 1998; Lázaro et al. 2015; Schneider et al. 2015; BuenfilRojas et al. 2018), detailed information on the actual part of the scute which had been used for analyses is generally missing, precluding further comparisons (Schneider et al. 2015). With the exception of 2 animals, our results show that $\mathrm{THg}$ concentrations significantly differ between full scutes (a combination of keratin, bone and connective tissues) and scute keratin layer, which can be explained by the poor affinity of $\mathrm{Hg}$ for bone tissue (Schneider et al. 2015), which results in the highest concentrations in the keratin layer (Fig. 3). In contrast, keratinized tissues of vertebrates such as hair/fur, feathers and claws generally display high $\mathrm{Hg}$ concentrations due to the affinity of $\mathrm{Hg}$ for the sulfhydryl groups contained in keratins (Appelquist et al. 1984, Schneider et al. 2012; Benjamin et al., 2018; Treu et al., 2018; Albert et al., 2019). Standardization of the analysed layers when scutes are used for $\mathrm{Hg}$ biomonitoring is therefore 
required to enable comparison between studies. In this respect, our results suggest that selecting the keratin layer should be favored as it avoids including unknown quantity of other tissue types (e.g., bone, connective tissues), thereby improving the evaluation of the actual environmental contamination status.

By providing a predictive equation of the relationship between $\mathrm{THg}$ concentrations found in full scutes and scute keratin layers of $C$. crocodilus, our study gives an objective tool to compare studies using both tissues for this species (both dry, Fig. 4).

\section{Relationships between tissues}

THg concentrations were higher in scutes and claws than in the RBCs and total blood (Table 2; Fig. 5). Blood is involved in the transport of $\mathrm{Hg}$ to different organs and represents the recent $\mathrm{Hg}$ exposure of the animal via its diet, one source of variation in $\mathrm{Hg}$ contamination in crocodilians (Lemaire et al. 2021a). In crocodilians, Hg concentrations in the blood are known to be related to $\mathrm{Hg}$ concentrations of internal tissues due to dynamic transfer in tissues involved in elimination (keratinized tissues), excretion (kidneys), detoxification (liver) and storage (muscles) (Eggins et al. 2015; Nilsen et al. 2017a). In contrast to blood, keratinized tissues are known to reflect the long-term exposure due to the non-reversible binding of $\mathrm{Hg}$ to the sulfhydryl residues of the keratins (Schneider et al. 2015; Lázaro et al. 2015, Marrugo-Negrete et al. 2019). A combination of non-lethal sampling of several tissues in caimans provides information on the recent (blood) and the long-term (keratinized tissues) Hg contamination of the individual, as well as the dynamics of $\mathrm{Hg}$ contamination over time, which had already been shown in other reptiles (Lemaire et al. 2018).

Our results show a positive correlation between the body size (SVL and TL) of the three species included in the study and the THg concentrations in claws and scutes (Table 3). In contrast, the THg concentration of RBCs was positively related to SVL in P. trigonatus solely. The THg 
concentration in total blood showed a positive relationship with the SVL and TL of $P$. trigonatus and C. crocodilus, but not with P. palpebrosus (Table 3). The variable relationship between blood $\mathrm{Hg}$ and body size is likely related to short-term variations in the diet of the individuals. Accordingly, such relationship was found in some studies on crocodilians (Eggins et al. 2015; Buenfil-Rojas et al. 2018; Lemaire et al. 2021a) but not in others (Yanochko et al. 1997; Eggins et al. 2015; Lawson et al. 2020). This emphasizes the complementarity of assessing $\mathrm{Hg}$ concentrations related to both long-term integration (i.e., keratinized tissues such as claws and scutes) and short-term exposure (i.e., blood) in biomonitoring studies.

\section{CONCLUSION}

Our results highlight the need to standardize the evaluation of $\mathrm{Hg}$ concentration in crocodilians between studies. The variation in moisture content between tissues and individual animals increases the variation in the reported $\mathrm{Hg}$ concentrations, and hence precludes robust comparison between studies. In order to avoid such shortcomings, researchers should perform trace elements quantification to report their results based on dry weight analytical procedures or should provide the information on the tissue moisture contents when studies report concentrations based on wet weight. In addition, our results emphasize the need to analyze scute keratin layer rather than full scutes in order to provide less variable and more reliable values of long-term $\mathrm{Hg}$ contamination of caimans. Finally, the simultaneous use of both blood and keratinized tissues in crocodilians offer the possibility to quantify different time scales of $\mathrm{Hg}$ exposure by non-lethal sampling. 


\section{Acknowledgments}

We are grateful to the authorities of Conseil Scientifique Régional du Patrimoine Naturel (CSRPN) and La Direction Générale des Territoires et de la Mer de Guyane (DGTM), which authorized our fieldwork. We would also like to thank the teams of "Réserve Naturelle des Nouragues", "Réserve Naturelle du Mont-Grand Matoury", "Réserve Naturelle Trésor", "Réserve Naturelle de la Trinité", "Réserve Naturelle de Kaw-Roura", "Pripis de Yiyi", the Conservatoire du Littoral, F. Starace, T. LePape, F. Beau and P. Gaucher for their help in the field, and E. Courtois, M. Dewynter and Q. Martinez for providing samples. This work was supported by the Office de l'Eau de Guyane; the Office Française pour la Biodiversité, the Direction Générale des Territoires et de la Mer de Guyane, the Zoo de Paris, the Fondation d'entreprise Hermès and the CNRS. We are grateful to C. Churlaud and M. Brault-Favrou from the "Plateforme Analyses Elémentaires" of LIENSs for their assistance during mercury analyses. The Institut Universitaire de France (IUF) is acknowledged for its support to P. Bustamante as a Senior Member. We thank the Nouragues Research Field Station (managed by CNRS) which benefits from "Investissement d'Avenir" grant managed by Agence Nationale de la Recherche (AnaEE France ANR-11-INBS-0001; Labex CEBA ANR-10-LABX-25-01), and its team for assistance in the field.

\section{REFERENCES}

Albert, C., Renedo, M., Bustamante, P., Fort, J. 2019. Using blood and feathers to investigate large-scale Hg contamination in Artic seabirds: A review. Environ. Res. 177, 108588.

Alibardi, L. (2003) Immunocytochemistry and keratinization in the epidermis of crocodilians. Zool. Stud. 42: 346-356.

Almli, B., Mwase, M., Sivertsen, T., Musonda, M.M., Flåøyen, A. (2005) Hepatic and renal concentrations of 10 trace elements in crocodiles (Crocodylus niloticus) in the Kafue and Luangwa rivbers in Zambia. Sci. Total Environ. 337: 75-82.

Appelquist, H., Asbirk, S., Drabaek, I. (1984) Mercury monitoring: mercury stability in bird feathers. Mar. Pollut. Bull. 15: 22-24.

Beau, F., Bustamante, P., Michaud, B., Brischoux, F. (2019) Environmental causes and reproductive correlates of mercury contamination in European pond turtles (Emys orbicularis). Environ. Res. 172: 338-244. 
Benjamin, T., Brasso, R., Midway, S., Thompson, D., Harden, L.A. 2018. Mercury (Hg) concentration in gravid Blanding's Turtles (Emydoidea blandingii) in Northeastern Illinois. Bull. Environ. Contam. Toxicol. 101, 295-299.

Benoit, J.M., Gilmour, C.C., Heyes, A., Mason, R.P., Miller, C.L. (2003) Geochemical and biological controls over methylmercury production and degradation in aquatic ecosystems. Am. Chem. Soc. Symp. Ser. 835: 262-297.

Buenfil-Rojas, A.M., Alvarez-Legorreta, T., Cedeño-Vázquez, J.R. (2018) Mercury and metallothioneins in blood fractions and tissues of captive Morelet's crocodiles in Quintana Roo, Mexico. Chemosphere 199: 630-636.

Buenfil-Rojas, A.M., Alvarez-Legorreta, T., Cedeño-Vazquez, J.R., Rendón-von Osten, J., González-Jáuregui, M. (2020) Distribution of metals in tissues of captive and wild Morelet's crocodiles and the potential of metallothioneins in blood fractions as a biomarker of metal exposure. Chemosphere 244: 125551.

Burella, P.M., Odetti, L.M., Simoniello, M.F., Poletta, G.L. 2018. Oxidative damage and antioxidant defense in Caiman latirostris (Broad-snouted caiman) exposed in ovo to pesticide formulations. Ecotox. Environ. Saf. 161, 437-443.

Burger, J., Gochfeld, M., Rooney, A.A., Orlando, E.F., Woodward, A.R., Guillette Jr, L.J. (2000) Metals and metalloids in tissues of American Alligators in three Florida lakes. Arch. Environ. Contam. Toxicol. 38: 501-508.

Campbell, J.W., Waters, M.N., Tarter, A., Jackson, J. (2010) Heavy metal and selenium concentrations in liver tissue from wild American alligator (Alligator mississippiensis) liver near Charleston, South Carolina. J. Wildl. Dis. 46: 1234-1241.

Campbell, K.R., (2003) Ecotoxicology of crocodilians. Appl. Herpetol. 1: 45-163.

Camus, A.C., Mitchell, M.M., Williams, J.F., Jowett, P.L.H., (1998) Elevated lead levels in farmed American alligators Alligator mississippiensis consuming nutria Myocastor coypus meat contaminated by lead bullets. J. World Aquacult. Soc. 3: 370-376.

Chumchal, M.M., Rainwater, T.R., Osborn, S.C., Roberts, A.P., Abel, M.T., Cobb, G.P., Smith, P.N., Bailey, F.C. (2011) Mercury speciation and biomagnification in the food web of Caddo Lake, Texas and Louisiana, USA, a subtropical freshwater ecosystem. Environ. Toxicol. Chem. 30: 1153-1162.

Cook, R.A., Behler, J., Breaitis, P., (1991) Elevated heavy metal concentrations in captive crocodilians-two cases. Proceedings, Annual Meeting of American Association of Zoo Veterinarians, Greensboro, North Carolina, 1989, pp.151. 
Day, R.D., Christopher, S.J., Becker, P.R., Whitakers, D.W. (2005) Monitoring mercury in the Loggerhead Sea Turtle, Caretta caretta. Environ. Sci. Technol. 39: 437-446.

Delany, M.F., Bell, J.U., Sundlof, S.F. (1988) Concentrations of contaminants in muscle of the American Alligator in Florida. J. Wildl. Dis. 24: 62-66.

De Thoisy, B., Hrbek, T., Farias, I.P., Vasconcelos, W.R., Lavergne, A. (2006) Genetic structure, population dynamics, and conservation of Black caiman (Melanosuchus niger). Biol. Conserv. 133: 474-482.

Eagles-Smith, C.A., Silbergeld, E.K., Basu, N., Bustamante, P., Diaz-Barriga, F., Hopkins, W.A., Kidd, K.A., Nyland, J.F. (2018) Modulators of mercury risk to wildlife and humans in the context of rapid global change. Ambio 47: 170-197.

Eggins, S., Schneider, L., Krikowa, F., Vogt, R.C., Silveira, R.D., Maher, W. (2015) Mercury concentrations in different tissues of turtle and caiman species from Rio Purus, Amazonas, Brazil. Environ. Toxicol. Chem. 34: 2771-2781.

Elsey, R.M., Lance, V.A., Campbell, L. (1999) Mercury levels in Alligator Meat in South Louisiana. Bull. Environ. Contam. Toxicol. 63: 598-603.

Ericksen, J.A., Gustin, M.S., Schorran, D.E., Johnson, D.W., Lindberg, S.E., Coleman, J.S. (2003) Accumulation of atmospheric mercury in forest foliage. Atmos. Environ. 37: 16131622.

Fitzgerald, W.F., Lamborg, C.H., Hammerschmidt, C.R. (2007) Marine biogeochemical cycling of mercury. Chem. Rev. 107: 641-662.

Guillette Jr., L.J, Crain, D.A., Gunderson, M.P., Kools, S.A.E., Milnes, M.R., Orlando, E.F., Rooney, A.A., Woodward, A.R. (2000) Alligators and endocrine disrupting contaminants: a current perspective. Amer. Zool. 40: 438-452.

Guillette Jr., L.J, Gross, T.S., Masson, G.R., Matter, J.M., Percival, H.F., Woodward, A.R. (1994) Developmental abnormalities if the gonad and abnormal sex hormone concentration in juvenile alligator from contaminated and control lakes in Florida. Environ. Health Perspect. 102: 680-688.

Harrell Jr., F.E., (2015) Regression modeling strategies: with applications to linear models, logistic regression, and survival analysis. Second ed. Springer Science \& Business Media, New York.

Horai, S., Itai, T., Noguchi, T., Yasuda, Y., Adachi, H., Hyobu, Y., Riyadi, A., Boggs, A.S.P., Lowers, R., Guillette Jr, L.J., Tanabe, S. (2014) Concentrations of trace elements in American alligators (Alligator mississippiensis) from Florida, USA. Chemosphere 108: 159167. 
Hsu-Kim, H., Eckley, C.S., Achá, D., Feng, X., Gilmour, C.C., Jonsson, S., Mitchell, C.P. (2018) Challenges and opportunities for managing aquatic mercury pollution in altered landscapes. Ambio 47: 141-169.

Jagoe, C.H., Arnold-Hill, B., Yanochko, G.M., Winger, P.V., Brisbin Jr, I.L. (1998) Mercury in alligators (Alligator mississippiensis) in the southeastern United States. Sci. Total Environ. 213: 255-262.

Jensen, S., Jernelöv, A. (1969) Biological methylation of mercury in aquatic organisms. Nature 223: 753-754.

Lawson, A.J., Moore, C.T., Rainwater, T.R., Nilsen, F.M., Wilkinson, P.M., Lowers, R.H., Guillette Jr., L.J., McFadden, K.W., Jodice, P.G.R. (2020) Nonlinear patterns in mercury bioaccumulation in American alligators are a function of predicted age. Sci. Total Environ. 707: 135103.

Lázaro, W.L., de Oliveira, R.F., dos Santos-Filho, M., da Silva, C.J., Ignácio, Á.R., Díez, S. (2015) Non-lethal sampling for mercury evaluation in crocodilians. Chemosphere 138: 2532.

Lemaire, J., Bustamante, P., Marquis, O., Caut, S., Brischoux, F. (2021b) Influence of sex, size and trophic level on blood $\mathrm{Hg}$ concentrations in Black caiman, Melanosuchus niger (Spix, 1825) in French Guiana. Chemosphere 262: 127819.

Lemaire, J., Bustamante, P., Olivier, A., Lourdais, O., Michaud, B., Boissinot, A., Galán, P., Brischoux, F. (2018) Determinants of mercury contamination in viperine snakes, Natrix maura, in Western Europe. Sci. Total Environ. 635: 20-25.

Lemaire, J., Marquis, O., Bustamante, P., Mangione, R., Brischoux, F. (2021a) I got it from my mother: Inter-nest variation of mercury concentration in neonate Smooth-fronted Caiman (Paleosuchus trigonatus) suggest maternal transfer and possible phenotypical effects. Environ. Res., in press. DOI: 10.1016/j.envres.2020.110494

Machkour-M'Rabet, S., Hénaut, Y., Charruau, P., Gevrey, M., Winterton, P., Legal, L. (2009) Between introgression events and fragmentation, islands are the last refuge for American crocodile in Caribbean Mexico. Mar. Biol. 156: 1321-1333.

Manolis, S., Webb, G., Briton, A. (2002) Crocodilians and other reptiles: bioindicators of pollution. In the Finnis River. In Markich, S.J., Jeffree, R.A., eds, A Natural Laboratory of Moning Impact- Past, Present and Future. Australian Nuclear Science and Technology Organisation (ANSTO), Clayton, Australia, pp. 65-69. 
Marrugo-Negrete, J., Durango-Hernández, J., Calao-Ramos, C., Urango-Cárdenas, I., Díez, S. (2019) Mercury levels and genotoxic effect in caimans from tropical ecosystems impacted by gold mining. Sci. Total. Environ. 664: 899-907.

Nilsen, F.M., Bowden, J.A., Rainwater, T.R., Brunell, A.M., Kassim, B.L., Wilkinson, P.M., Guillette Jr, L.J., Long, S.E., Schock, T.B. (2019) Examining toxic trace element exposure in American alligators. Environ. Int. 128: 324-334.

Nilsen, F.M., Dorsey, J.E., Lowers, R.H., Guillette Jr, L.J., Long, S.E., Bowden, J.A., Schock, T.B. (2017b) Evaluating mercury concentration and body condition in American alligators (Alligator mississippiensis) at Merritt Island National Wildlife Refuge (MINWR), Florida. Sci. Total Environ. 607-608: 1056-1065.

Nilsen, F.M., Kassim, B.L., Delaney, J.P., Lange, T.R., Brunell, A.M., Guillette Jr, L.J., Long, S.E., Schock, T.B. (2017a) Trace element biodistribution in the American alligator (Alligator mississippiensis). Chemosphere 181: 343-351.

Pacheco-Sierra, G., Gompert, Z., Dominguez-Laso, J., Vazquez-Dominguez, E. (2016) Genetic and morphological evidence of a geographically widespread hybrid zone between two crocodile species, Crocodylus acutus and Crocodylus moreletii. Mol. Ecol. 25: 3484-3498.

R Core Team, 2013. R: A Language and Environment for Statistical Computing. R foundation for Statistical Computing, Vienna, Austria. http://www.R-project.org/.

Rainwater, T.R., Wu, T.H., Finger, A.G., Cañas, J.E., Yu, L., Reynolds, K.D., Coimbatore, G., Barr, B., Platt, S.G., Cobb, G.P., Anderson, T.A., McMurry, S.T. (2007) Metals and organochlorine pesticides in caudal scutes of crocodiles from Belize and Costa Rica. Sci. Total. Environ. 373: 146-156.

Richardson, K.C., Weeb, G.J.W., Manolis, S.C. (2002) Crocodiles: Inside Out: A Guide to the Crocodilians and Their Functional Morphology. Surrey Beatty \& Sons, Australia, pp. 1-172.

Rivera, S.J., Pacheco, L.F., Achá, D., Molina, C.I., Miranda-Chumacero, G. (2016) Low total mercury in Caiman yacare (Alligatoridae) as compared to carnivorous, and non-carnivorous fish consumed by Amazonian indigenous communities. Environ. Pollut. 218: 233-371.

Rumbold, D.G., Fink, L.E., Laine, K.A., Niemczyk, S.L., Chandrasekhar, T., Wankel, S.D., Kendall, C. (2002) Levels of mercury in alligators (Alligator mississippiensis) collected along a transect through the Florida Everglades. Sci. Total Environ. 297: 239-252.

Santos, X., Navarro, S., Campos, J.C., Sanpera, C., Brito, J.C. (2018) Stable isotopes uncover trophic ecology of the West African crocodile (Crocodylus suchus). J. Arid Environ. 148: 613. 
Scheuhammer, A.M., Sandheinrich, M.B. (2007) Recent advances in the toxicology of methylmercury in wildlife. Ecotoxicology 17: 67-68.

Schneider, L., Eggins, S., Maher, W., Vogt, R.C., Krikowa, F., Kinsley, L., Eggins, S.M., Da Silveira, R., (2015) An evaluation of the use of reptile dermal scutes as a non-invasive method to monitor mercury concentrations in the environment. Chemosphere 119: 163-170.

Schneider, L., Peleja, R.P., Kluczkovski Jr, A., Freire, G.M., Marioni, B., Vogt, R.C., Da Silveira, R. (2012) Mercury concentration in the spectacled caiman and black caiman (Alligatoridae) of the Amazon: implications for human health. Arch. Environ. Contam. Toxicol. 63: 270-279.

Selin, N.E. (2009) Global biogeochemical cycling of mercury: a review. Annu. Rev. Environ. Resour. 34: 43-63.

Siroski, P.A., Poletta, G.L., Latorre, M.A., Merchant, M.E., Ortega, H.H., Mudry, M.D. (2016) Immunotoxicity of commercial-mixed glyphosate in broad snouted caiman (Caiman latirostris). Chem. Biol. Interact. 244: 64-70.

Somaweera, R., Nifong, J., Rosenblatt, A., Brien, M.L., Combrink, X., Elsey, R.M., Grigg, G., Magnusson, W.E., Mazzotti, F.J., Pearcy, A., Platt, S.G., Shirley, M.H., Tellez, M., Van der Ploeg, J., Webb, G., Whitaker, R., Webber, B.L. (2020) The ecological importance of crocodylians: towards evidence-based justification for their conservation. Biol. Rev. 95: 936959.

Treu, G., Krone, O., Unnsteinsdóttir, E.R., Greenwood, A.D., Czirják, G.Á. 2018. Correlations between hair and tissue mercury concentrations in Icelandic arctic foxes (Vulpes lagopus). Sci. Total Environ. 619-620, 1589-1598.

Trillanes, C.E., Pérez-Jiménez, J.C., Rosíles-Martínez, R., González-Jáuregui, M. (2014) Metals in Caudal Scutes of Morelet's Crocodile (Crocodylus moreletii) from the Southern Gulf of Mexico. Bull. Environ. Contam. Toxicol. 93: 423-428.

Vieira, L.M., Nunes, V. da S., Amaral, M.C. do A., Oliveira, A.C. Hauser-Davis, R.A., Campos, R.C. (2011) Mercury and methyl mercury ratios in caimans (Caiman crocodilus yacare) from the Pantanal areas, Brazil. J. Environ. Monit. 13: 280-287.

Yanochko, G., Jagoe, C., Brisbin Jr, L. (1997) Tissue mercury concentrations in alligators (Alligator mississippiensis) from the Florida Everglades and the Savannah River site, Carolina. Arch. Environ. Contam. Toxicol. 32: 323-328. 
Table 1. Proportion of moisture (\%, Mean \pm SD (coefficient of variation), [min - max] in claws, scutes and total blood of smooth-fronted caiman (Paleosuchus trigonatus), spectacled caiman (Caiman crocodilus) and dwarf caiman (Paleosuchus palpebrosus) from French Guiana. n: number of samples.

\begin{tabular}{|l|ccc|}
\hline Species & Moisture content in claws (n) & Moisture content in scutes (n) & Moisture content in total blood (n) \\
\hline Caiman crocodilus & $25.7 \pm 4.5(17.5)$ & $39.9 \pm 19.3(48.3)$ & $72.1 \pm 9.5(13.2)$ \\
& {$[15.3-47.1](29)$} & {$[13.5-81.3](28)$} & {$[57.3-88.7](20)$} \\
Paleosuchus palpebrosus & $20.7 \pm 4.1(19.8)$ & $26.4 \pm 4.4(16.7)$ & $78.9 \pm 0.2(0.3)$ \\
& {$[15.5-26.0](5)$} & {$[20.1-31.5](5)$} & {$[78.8-79.0](2)$} \\
Paleosuchus trigonatus & $46.1 \pm 15.2(33.0)$ & $55.3 \pm 21.6(47.2)$ & $72.9 \pm 19.2(26.3)$ \\
& {$[14.8-65.0](23)$} & {$[14.4-90.1](25)$} & {$[39.2-90.3](9)$} \\
\hline
\end{tabular}




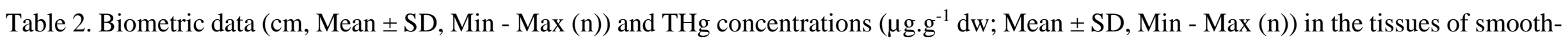
fronted caiman, Paleosuchus trigonatus, spectacled caiman, Caiman crocodilus and dwarf caiman, Paleosuchus palpebrosus, in French Guiana. SVL: Snout Vent Length; TL: Total Length; RBCs: Red Blood Cells; n: number of samples.

\begin{tabular}{|c|c|c|c|c|c|c|}
\hline Species & SVL & TL & THg claws & THg scutes & THg RBCs & THg Total blood \\
\hline Paleosuchus trigonatus & $\begin{array}{l}33.32 \pm 19.81 \\
10.90-81(51)\end{array}$ & $\begin{array}{l}62.11 \pm 36.42 \\
22.8-143(51)\end{array}$ & $\begin{array}{l}2.420 \pm 1.905^{\mathrm{a}}, \\
0.147-7.509(50)\end{array}$ & $\begin{array}{l}3.332 \pm 3.066^{\mathrm{a}} \\
0.087-9.859(48)\end{array}$ & $\begin{array}{l}0.447 \pm 0.270^{\mathrm{b}} \\
0.049-0.774(11)\end{array}$ & $\begin{array}{l}0.300 \pm 0.178^{b} \\
0.032-0.738(24)\end{array}$ \\
\hline Caiman crocodilus & $\begin{array}{l}32.70 \pm 13.57 \\
14.5-103(48)\end{array}$ & $\begin{array}{l}66.60 \pm 24.11 \\
31.0-176.0(48)\end{array}$ & $\begin{array}{l}2.692 \pm 1.608^{a} \\
0.321-8.807(48)\end{array}$ & $\begin{array}{l}2.638 \pm 1.497^{\mathrm{a}} \\
0.307-7.407(47)\end{array}$ & $\begin{array}{l}0.963 \pm 0.612^{b} \\
0.145-2.244(26)\end{array}$ & $\begin{array}{l}0.605 \pm 0.380^{\mathrm{b}} \\
0.089-1.532(40)\end{array}$ \\
\hline Paleosuchus palpebrosus & $\begin{array}{l}38.12 \pm 15.29 \\
16.5-62(12)\end{array}$ & $\begin{array}{l}79.42 \pm 33.22 \\
34.2-150(13)\end{array}$ & $\begin{array}{l}8.351 \pm 4.965^{\mathrm{a}} \\
2.028-20.042(13)\end{array}$ & $\begin{array}{l}7.647 \pm 4.742^{a} \\
0.789-15.628 \\
(13)\end{array}$ & $\begin{array}{l}2.364 \pm 1.884^{b} \\
0.447-5.775(6)\end{array}$ & $\begin{array}{l}1.376 \pm 0.986^{b} \\
0.540-3.415(7)\end{array}$ \\
\hline
\end{tabular}

THg values marked with the same letter ( $\mathrm{a}$ or $\mathrm{b}$ ) are not statistically different (Pairwise Bergmann-Hommel test, $\mathrm{p}<0.05$ ), test performed independently for the three species. 
Table 3. Relationship between body size $(\mathrm{cm})$ and $\mathrm{THg}$ concentration $\left(\mu \mathrm{g} \cdot \mathrm{g}^{-1} \mathrm{dw}\right)$ in tissues, and THg concentration between tissues of smooth-fronted caiman, Paleosuchus trigonatus, spectacled caiman, Caiman crocodilus and dwarf caiman, Paleosuchus palpebrosus. Values refer to $\rho$ (Spearman rank test) and significant relationships are in bold. Sample sizes are given in parenthesis. $\mathrm{TL}=$ Total Length; $\mathrm{SVL}=$ Snout Vent Length; RBCs: Red Blood Cells.

\begin{tabular}{|c|c|c|c|c|c|}
\hline & TL & SVL & THg Scutes & THg Claws & THg RBCs \\
\hline \multicolumn{6}{|c|}{ Paleosuchus trigonatus } \\
\hline THg Scutes & $\mathbf{0 . 8 7 7}(48)$ & $\mathbf{0 . 8 8 5}(48)$ & - & - & - \\
\hline THg Claws & $\mathbf{0 . 8 4 2}(50)$ & $\mathbf{0 . 8 5 0}(50)$ & $0.945(48)$ & - & - \\
\hline THg RBCs & $0.451(11)$ & $\mathbf{0 . 6 2 3}(11)$ & $0.614(10)$ & $0.614(10)$ & - \\
\hline THg Total Blood & $\mathbf{0 . 7 3 0}(24)$ & $\mathbf{0 . 7 6 9}(24)$ & $\mathbf{0 . 8 9 7}(21)$ & $0.914(23)$ & $0.771(6)$ \\
\hline \multicolumn{6}{|c|}{ Caiman crocodilus } \\
\hline THg Scutes & $\mathbf{0 . 4 5 9}(47)$ & $\mathbf{0 . 4 7 2}(47)$ & - & - & - \\
\hline THg Claws & $0.468(48)$ & $\mathbf{0 . 4 7 5}(48)$ & 0.909 (47) & - & - \\
\hline THg RBCs & $0.353(26)$ & $0.388(26)$ & $0.894(25)$ & $\mathbf{0 . 8 1 1}(26)$ & - \\
\hline THg Total Blood & $0.386(40)$ & $\mathbf{0 . 3 9 9}(40)$ & $\mathbf{0 . 8 8 2}(39)$ & $\mathbf{0 . 8 7 0}(40)$ & $0.992(25)$ \\
\hline \multicolumn{6}{|c|}{ Paleosuchus palpebrosus } \\
\hline THg Scutes & $\mathbf{0 . 8 3 1}(13)$ & $\mathbf{0 . 8 4 6}(12)$ & - & - & - \\
\hline THg Claws & $0.945(13)$ & $\mathbf{0 . 9 3 7}(12)$ & $0.857(13)$ & - & - \\
\hline THg RBCs & $0.771(6)$ & $0.600(5)$ & $0.829(6)$ & $0.657(6)$ & - \\
\hline THg Total Blood & $0.750(7)$ & $0.600(6)$ & $0.643(7)$ & $0.607(7)$ & $0.900(5)$ \\
\hline
\end{tabular}




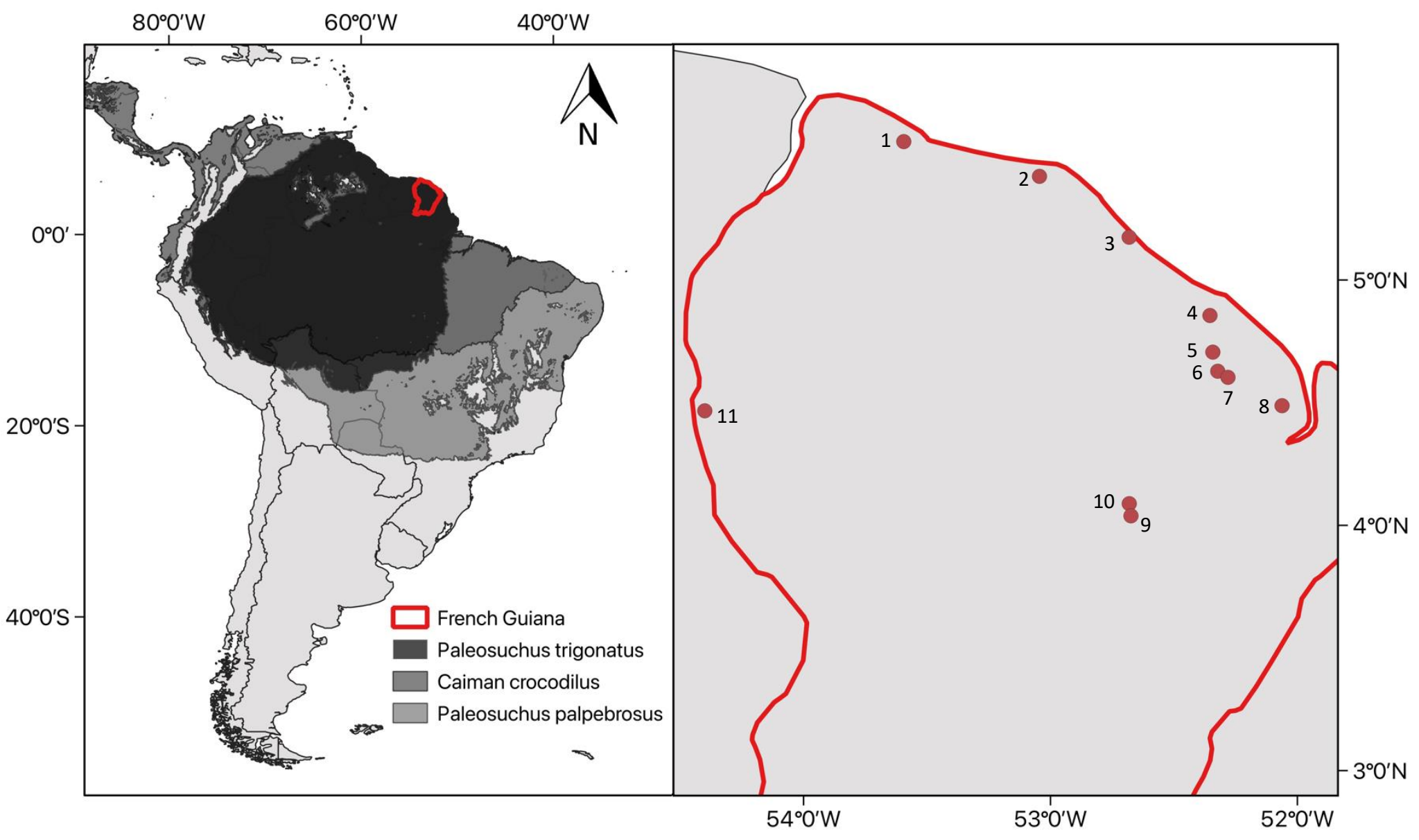


Figure 1. Location of French Guiana, distribution ranges and capture locations of the spectacled caiman, Caiman crocodilus (sites 2, 8), the smooth-

fronted caiman, Paleosuchus trigonatus (sites 3, 4, 7, 9, 10, 11) and the dwarf caiman, Paleosuchus palpebrosus (sites 1, 2, 5, 6). (Data for distribution ranges provided by The IUCN Red List of Threatened Species) 


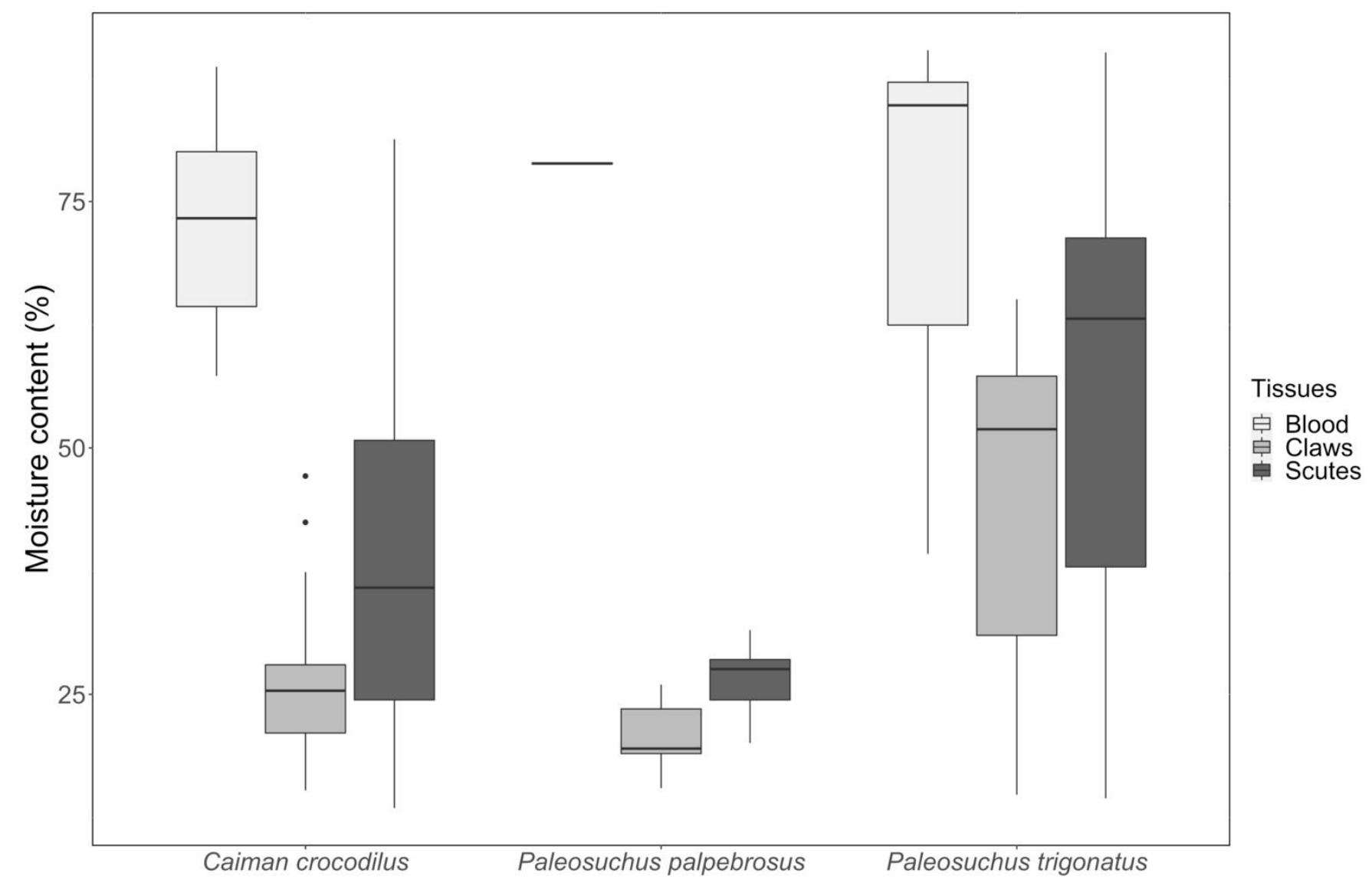

Figure 2. Moisture content measured in total blood, claws and scutes (\%) of spectacled caiman, Caiman crocodilus, dwarf caiman, Paleosuchus palpebrosus, and smooth-fronted caiman, Paleosuchus trigonatus, in French Guiana. The top and bottom of the boxes represent the first and last quartiles, the line across the box represents the median, the whiskers represent the fifth and ninety-fifth percentiles, and the circles represent outliers. 


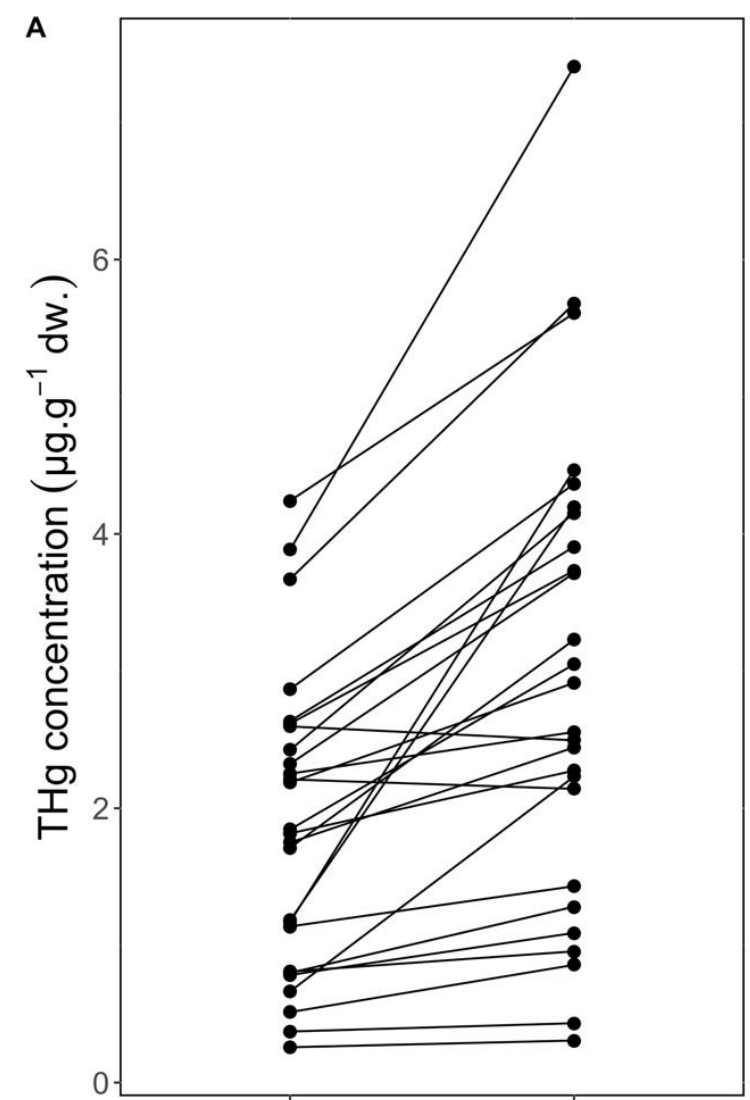

Full scute Keratine layers

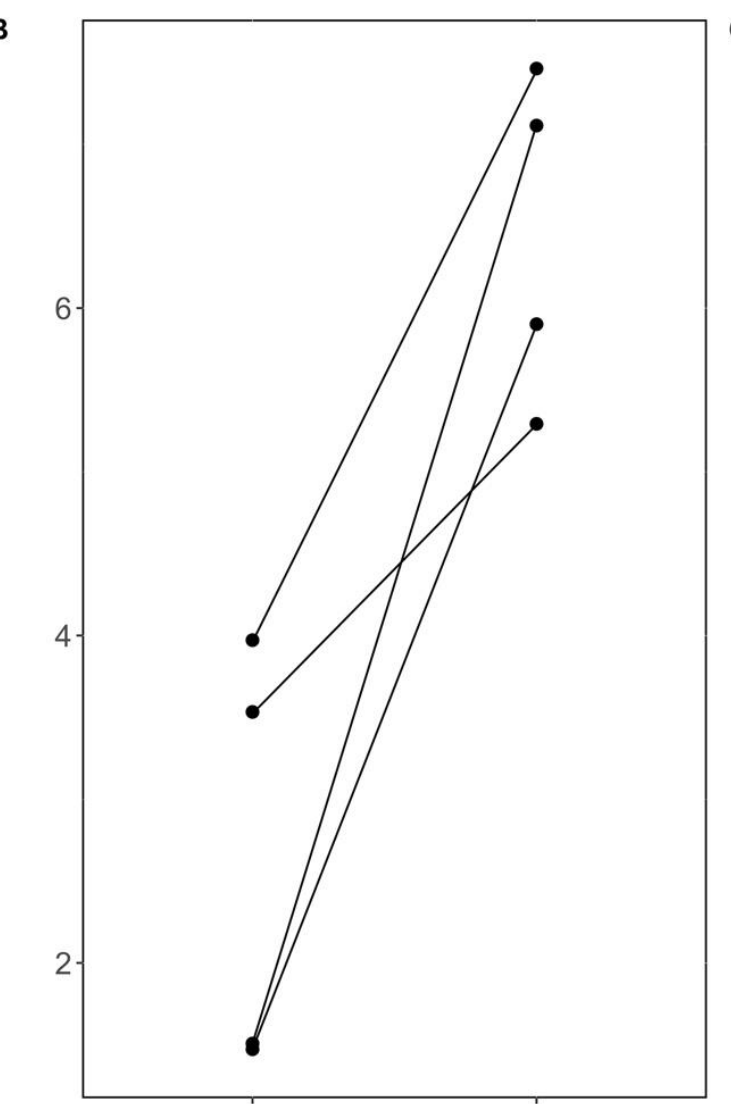

Full scute Keratine layers

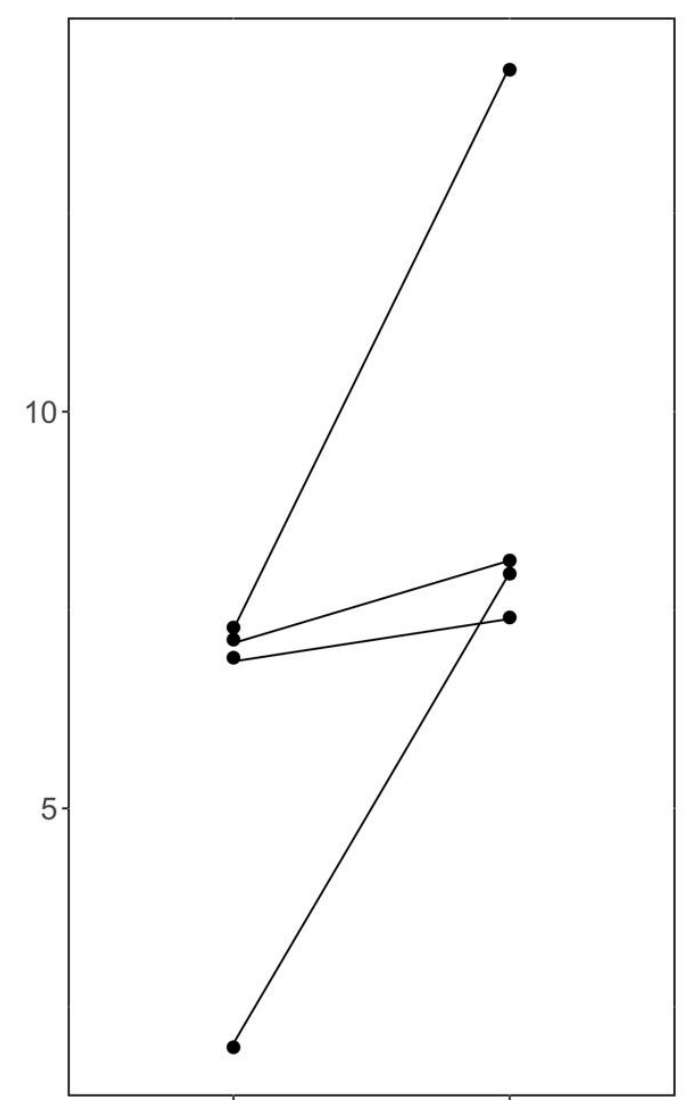

Full scute Keratine layers

Figure 3. THg concentrations measured in full scutes and scute keratin layers $\left(\mu \mathrm{g} \cdot \mathrm{g}^{-1} \mathrm{dw}\right)$ of spectacled caiman, Caiman crocodilus $(\mathbf{A}: \mathrm{n}=26$, paired t-test: $\mathrm{t}=-5.44, \mathrm{p}<0.001)$, smooth-fronted caiman, Paleosuchus trigonatus $(\mathbf{B}: \mathrm{n}=4$, paired $\mathrm{t}$-test: $\mathrm{t}=-4.71, \mathrm{p}=0.02)$ and dwarf caiman, Paleosuchus palpebrosus $(\mathbf{C}: \mathrm{n}=4$, paired t-test: $\mathrm{t}=-2.18, \mathrm{p}=0.12)$, in French Guiana. Each pair of connected dots correspond to one individual. 


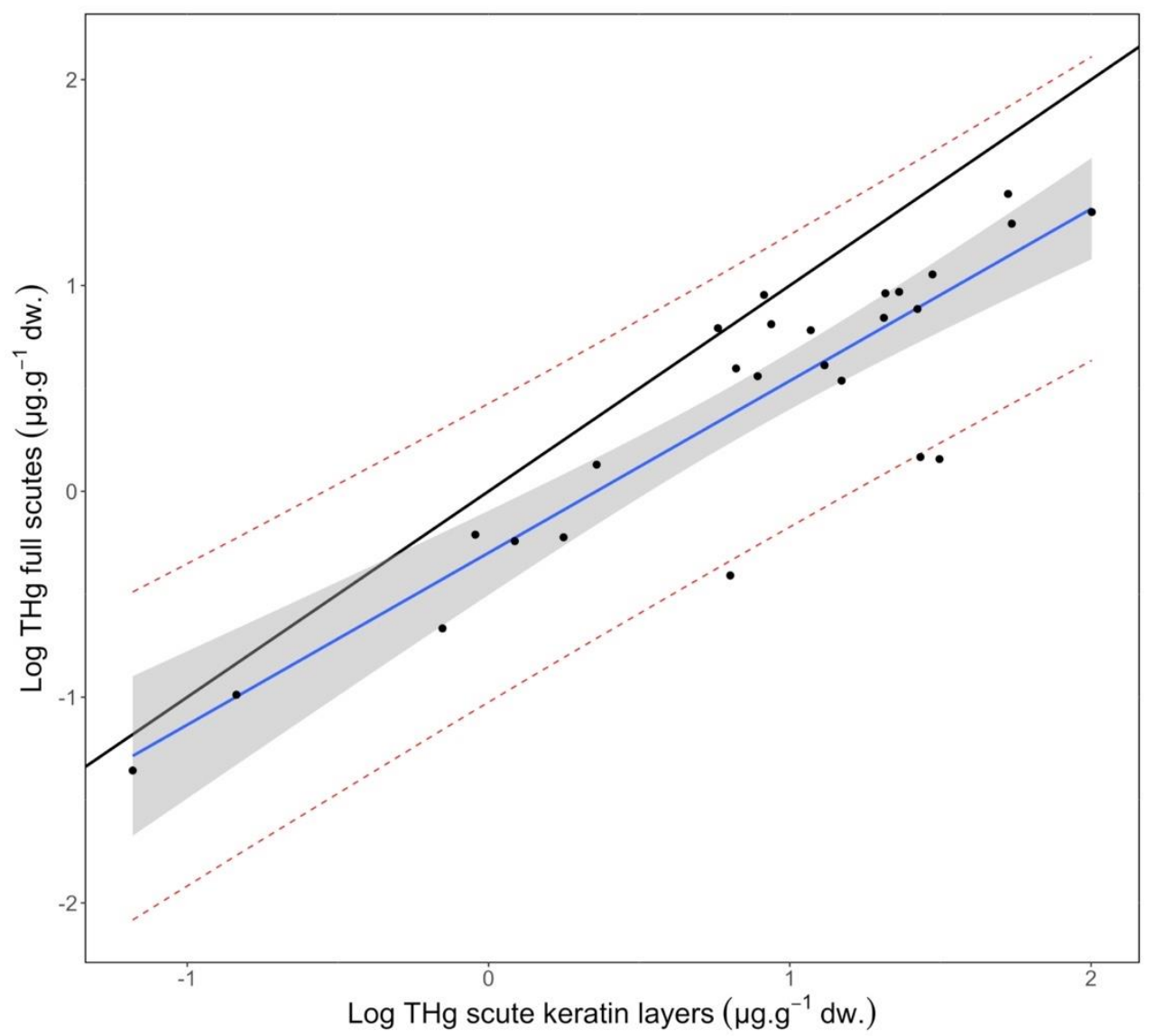

Figure 4. Linear regression between the mercury ( $\mathrm{THg}$ ) concentration in full scutes and scute keratin layers (in $\mu \mathrm{g} \cdot \mathrm{g}^{-1} \mathrm{dw}$ ) of the spectacled caiman (Caiman crocodilus; $\mathrm{n}=26 ; \mathrm{F}_{1-24}=93.67, \mathrm{R}^{2}=0.78, \mathrm{p}<0.001$ ). Regression lines (in red) with $95 \%$ confidence intervals indicate highly significant relationships between two tissues. The black line represents isometric scaling (ratio 1:1 between the two tissues). 


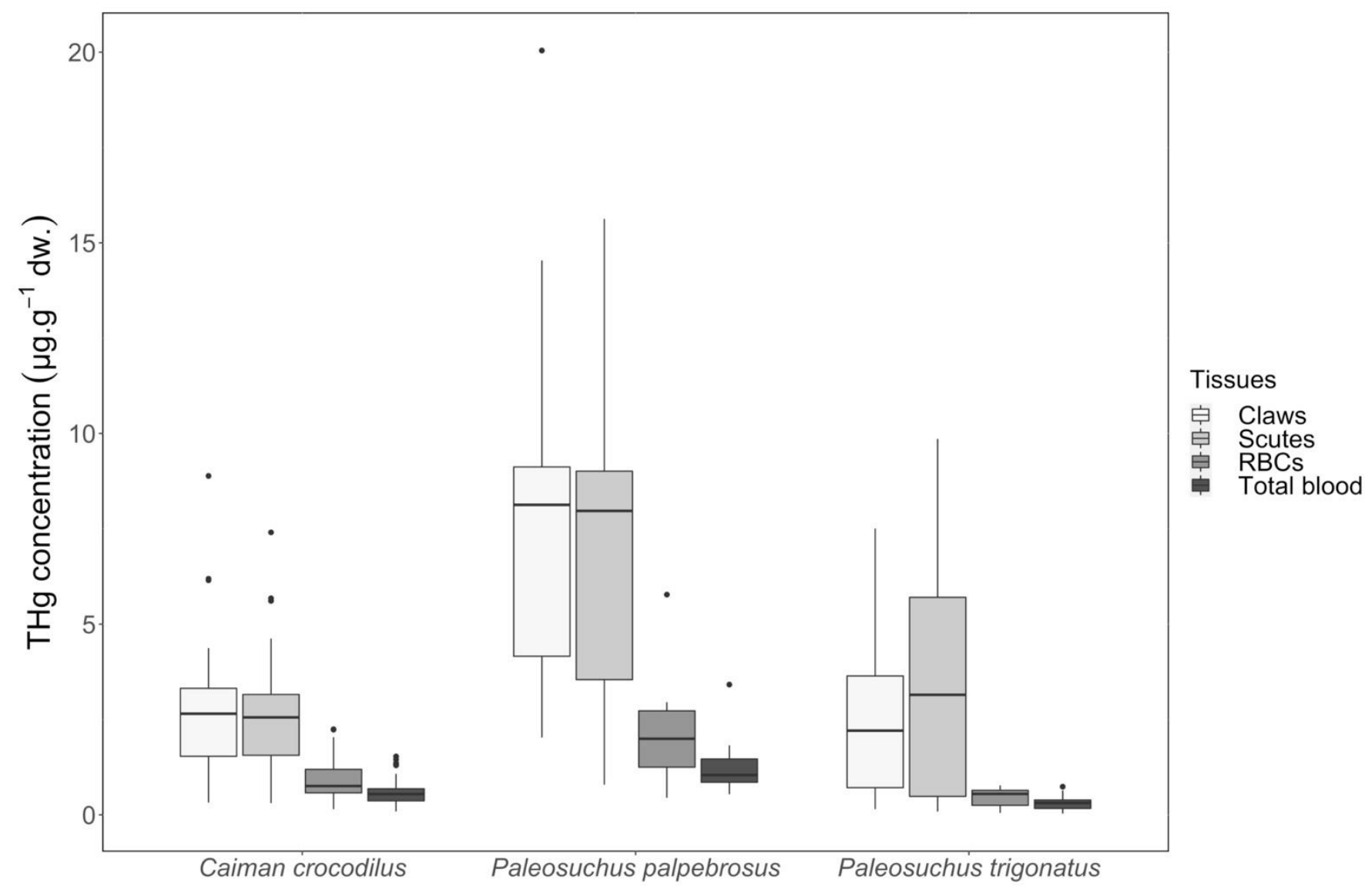

Figure 5. THg concentrations measured in claws, scutes, red blood cells (RBCs) and total blood ( $\mu$ g. $\mathrm{g}^{-1} \mathrm{dw}$ ) of spectacled caiman, Caiman crocodilus, dwarf caiman, Paleosuchus palpebrosus and smooth-fronted caiman, Paleosuchus trigonatus, in French Guiana. The top and bottom of the boxes represent the first and last quartiles, the line across the box represents the median, the whiskers represent the fifth and ninety-fifth percentiles, and the circles represent outlier. 